\title{
Social Inquiry Field Work Based Instruction Model To Improve Understanding Environmental Friendly Activities
}

\author{
Disman $^{1}$, Susanti Kurniawati ${ }^{2}$, Puspo Dewi Dirgantari ${ }^{3}$ \\ Program Studi Pendidikan Ekonomi, FPEB, Universitas Pendidikan Indonesia, Bandung, Indonesia ${ }^{1}$ \\ Program Studi Pendidikan Ekonomi, FPEB, Universitas Pendidikan Indonesia, Bandung, Indonesia ${ }^{2}$ \\ Program Studi Pendidikan Bisnis, FPEB, Universitas Pendidikan Indonesia, Bandung, Indonesia ${ }^{3}$
}

\begin{abstract}
This research is motivated by economic learning conditions that have not involved the value of sustainability. Sustainability values need to be developed in economic learning because economic activities have a great opportunity to behave in an environmentally unfriendly manner that has a broad impact. The application of sustainable values to students is realized through meaningful learning, one of which is by applying the inquiry work field learning model that emphasizes direct experience through field research. Thus this study aims to design learning models with the ADDIE approach (analysis, design, development, implementation and evaluation). To design the design of this learning model, a needs analysis was conducted and design was designed by conducting surveys, observations and literature studies on the learning model. The results of this study reveal the current conditions of economic learning, the results of the needs analysis for the preparation of learning models and the design of learning models. It is hoped that from this research, it can be an input for meaningful economic learning through direct experience that is able to foster environmentally friendly behavior in the long term.
\end{abstract}

Keyword. learning, inquiry; economics; fieldwork.

Article history. Received Agustus, 2018. Revised Oktober, 2018.Accepted December, 2018

Corresponding Author. Email: susanti.kurniawati@upi.edu, puspodewi@upi.edu

How to cite article. Kurniawati, S., \& Dirgantari, P. D. (2018). Social Inquiry Field Work Based Instruction Model To Improve Understanding Environmental Friendly Activities. The International Journal of Business Review (The Jobs Review), 1(2), 109-114.

https://doi.org/https://doi.org/10.17509/tjr.v1i2.14475

\section{INTRODUCTION}

The long-term sustainability of resource use is one of the things that must be considered in efforts to explore and exploit resources. This is what is called the concept of consumption sustainability. Behaviors that are counter to the concept of sustainability are wasteful use of energy, use of non-environmentally friendly products and actions that cause waste and pollution. Non-environmentally friendly behavioral phenomena can be seen from the use of ozone-depleting substances (BPO), B3 materials (hazardous and toxic materials), high amounts of waste that are difficult to recycle, high deforestation and high use of goods produced in ways that are not environmentally friendly like, paper, tissue, cotton, tampons and herbal items.

In daily activities students often find various environmentally unfriendly behaviors and the effects of these behaviors. To be able to be environmentally friendly, students must be able to criticize good and bad conditions of environmentally unfriendly behavior and environmental conditions that have not supported their lives such as unhealthy environments.

At the tertiary level, especially in the Economics, exploitation and resource use study programs, it is reviewed in the Resource Economics course. The thing that needs to be 


\section{DISMAN, SUSANTI KURNIAWATI,, PUSPO DEWI DIRGANTARI/Social Inquiry Field Work Based Instruction Model To Improve Understanding Environmental Friendly Activities}

improved on ESD learning now is the lack of understanding of students on environmental issues which is a global issue. The negative impact of economic activity on the environment has been at a critical point where there is often scarcity of resources as input to production. In addition, the delivery of ESD material is less varied / monometode. In fact, ESD material is very closely related to natural and social conditions, so learning based on field research is very suitable for this research. One effort in the field of education to overcome this problem is to provide an understanding of the environment in the concept of green economy. This concept is packaged in the learning of Resource Economics with the material of the Green Economy. Learning model that is expected to be able to develop an understanding of new concepts. Therefore, the inquiry learning model is used based on field work to improve students' understanding. Inquiry learning is one of the learning methods adapted from science learning that aims to increase the ability of students to make decisions and solve problems in accordance with learning objectives (Fiedel et. Al: 2008). Inquiry based learning acquires knowledge from research (Bransford, Brown \& Cocking: 2000).

\section{RESEARCH METHOD}

The research method that will be used is the experimental method used is a quasi experiment, which is experimentation conducted with intact group subjects and not randomly taken subjects to be treated. The design that will be used is Control Group PretestPosttest Design, consisting of a group of experimental students with learning inquiry-based fieldwork learning models and control groups with conventional models (lecture method).

\section{RESULTS AND DISCUSSION}

In applying the learning method that will be used, it is necessary to ensure that the learning method that will be designed is really needed by the user. To find out that this method is needed, a needs analysis is carried out, the results of the needs analysis are as follows:

Table 1. Need Assesment of Inquiry Based Field Work Method of Instruction

\begin{tabular}{|c|c|c|}
\hline No & Statement & $\%$ \\
\hline 1. & $\begin{array}{l}\text { Lecturer responses regarding the importance of developing inquiry based field work models } \\
\text { in learning Resource Economics (ESD) to provide meaningful learning experiences . }\end{array}$ & $71 \%$ \\
\hline 2. & $\begin{array}{l}\text { Lecturer responses regarding the importance of developing inquiry based field work models } \\
\text { in learning Resource Economics (ESD) to provide meaningful learning experiences }\end{array}$ & $62 \%$ \\
\hline 3. & $\begin{array}{l}\text { Students' responses to the need for learning that provide direct experience to facilitate } \\
\text { understanding }\end{array}$ & $84 \%$ \\
\hline 4. & The response of students is the need for meaningful learning through the inquiry approach & $78 \%$ \\
\hline 5. & $\begin{array}{l}\text { The response of students is that the development of ESD learning methods needs to be more } \\
\text { meaningful. }\end{array}$ & $88 \%$ \\
\hline 6. & $\begin{array}{l}\text { The response of students is the need for sustainability values in economic learning so that } \\
\text { they contribute more to the environment. }\end{array}$ & $83 \%$ \\
\hline 7. & $\begin{array}{l}\text { The response of students is the need for sustainability values in economic learning so that } \\
\text { they contribute more to the environment.. }\end{array}$ & $52 \%$ \\
\hline 8. & The response of students that learning with field research is able to change the mindset & $83 \%$ \\
\hline 9. & $\begin{array}{l}\text { The response of students is that learning from field research that provides direct experience } \\
\text { can change behavior. }\end{array}$ & $75 \%$ \\
\hline
\end{tabular}

Source : Primar 2018

Based on needs analysis, this method is needed to improve understanding through direct experience. This immediate experience can change the mindset and preach the behavior of students. 
Furthermore, the development of the learning material with ADDIE was compiled. The results of the method development obtained the following results:

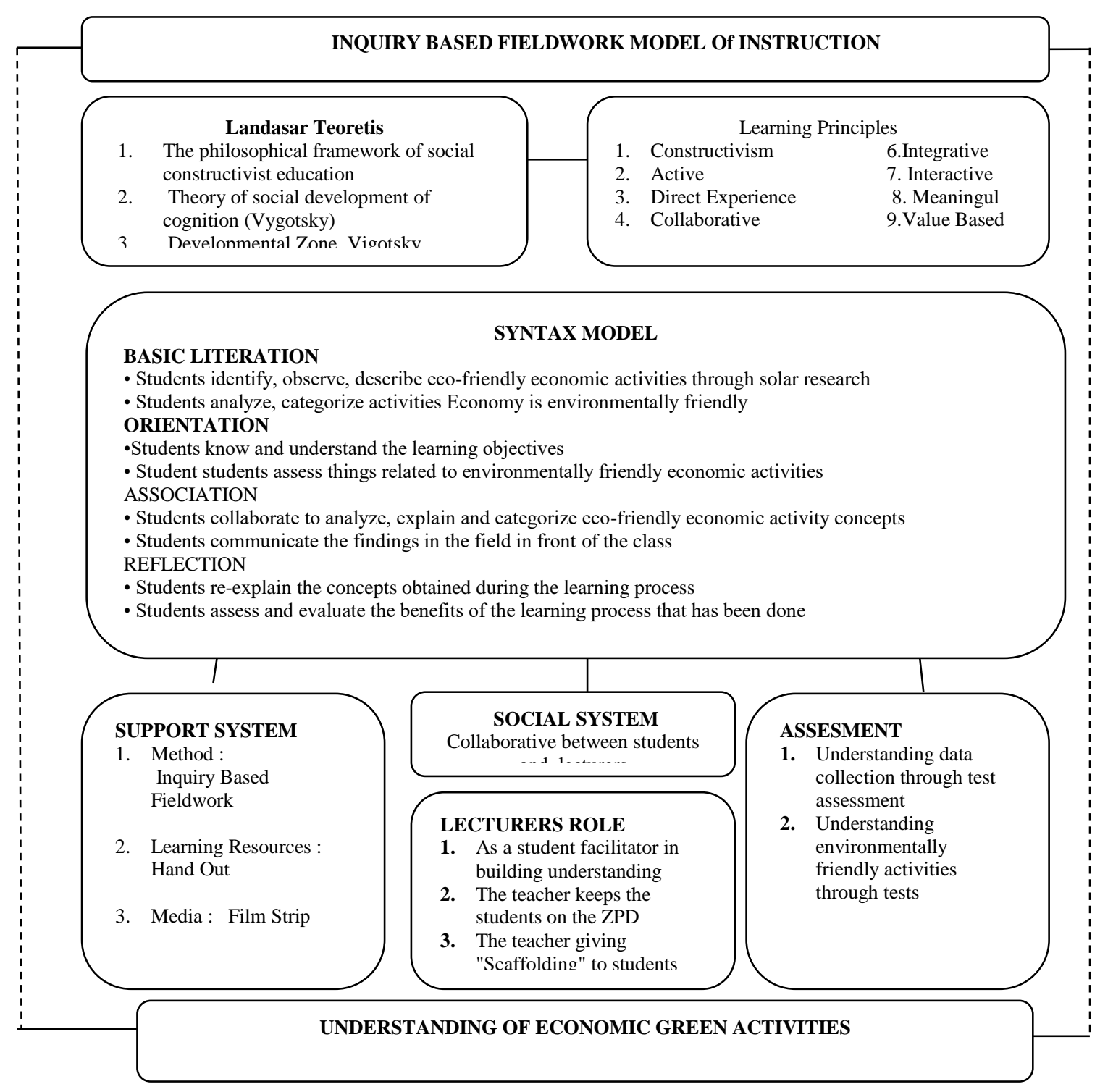

After applying twice the treatment in the control class and experimental class, twice and evaluated, the results obtained as shown in Figure 1 below: 


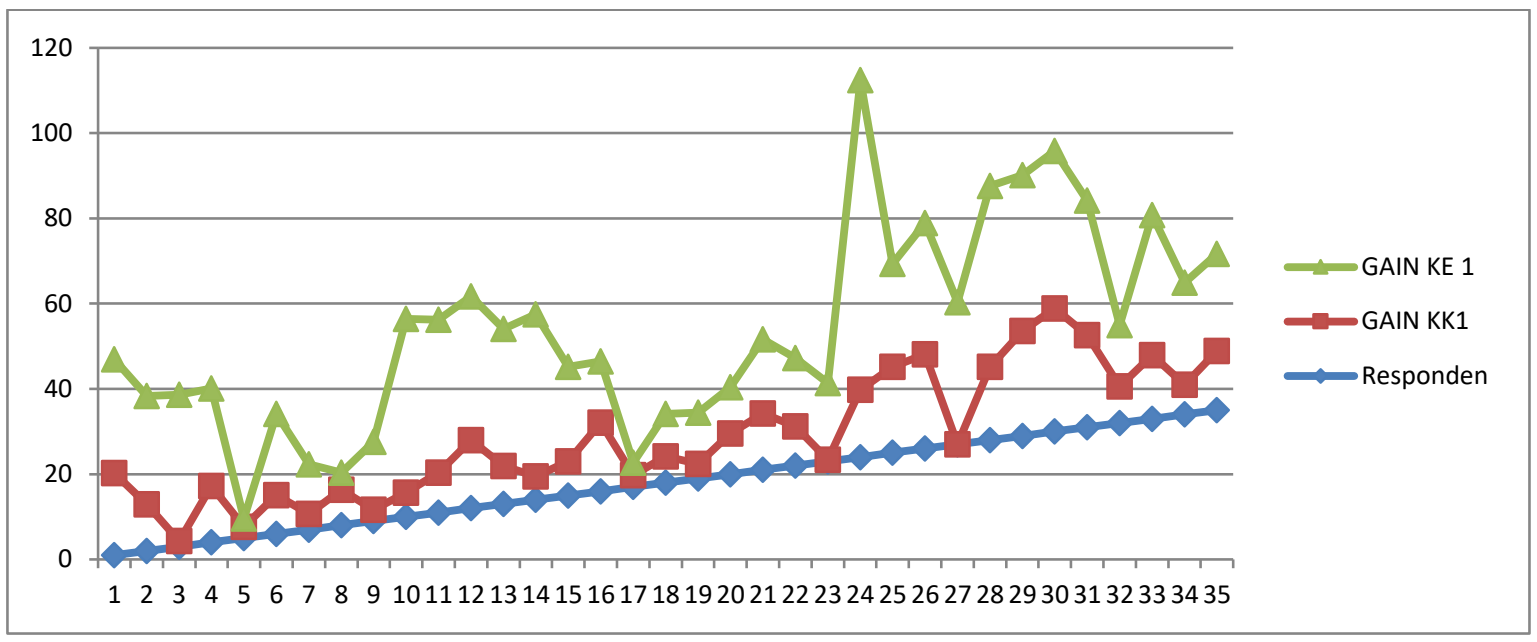

Figure 2. Increasing Student's Understanding Score on Economics Green Activities (1st treatment)

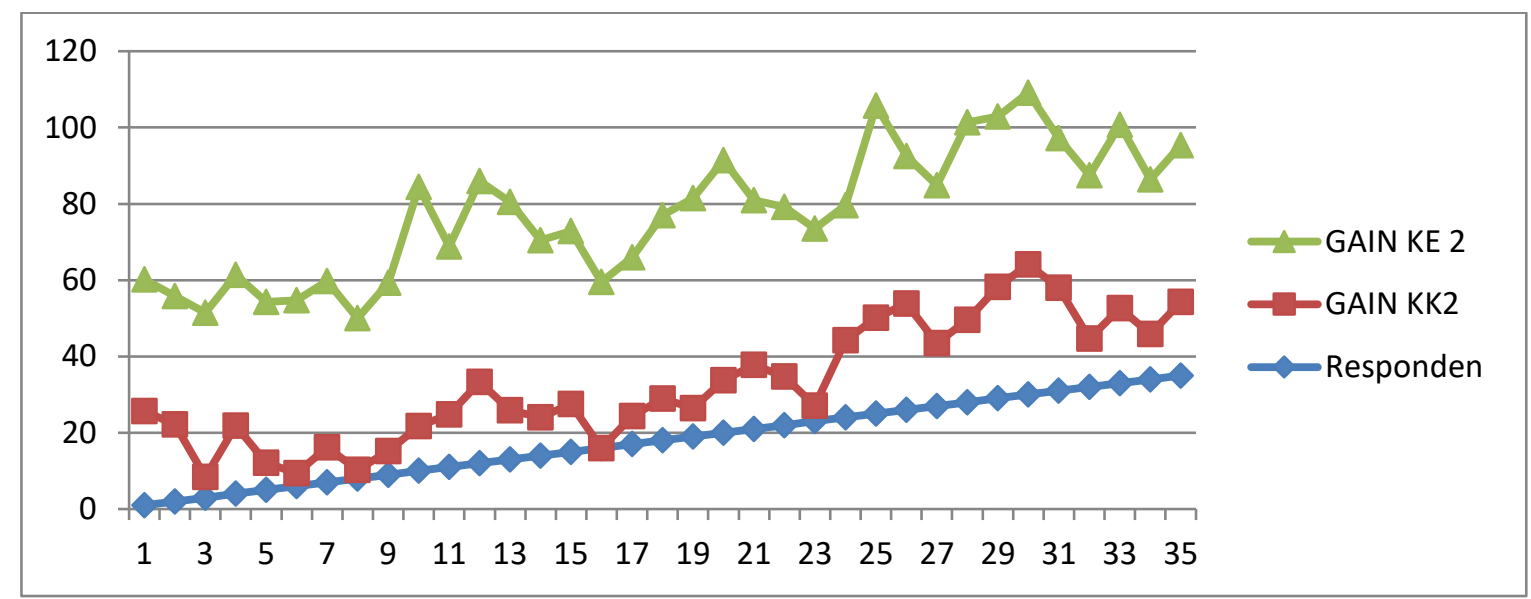

Figure 3 : Increasing Student's Understanding Score on Economics Green Activities (2nd treatment)

In Figure 1 and Figure 2, there appears to be an increase in students' understanding after treatment 1 and 2 . After $t$ test, it can be stated that there is a significant increase in the experimental class with the inqiry based field method with the control class using the lecture method. This increase indicates that inquiry-based field methods effectively improve students' understanding abilities. Theoretically this happens because this method is based on the research of students to locations related to environmentally friendly economic activities such as markets, factories, public facilities and others;

\section{CONCLUSION}

One effort in the field of education to overcome this problem is to provide an understanding of the environment in the concept of green economy. This concept is packaged in the learning of Resource Economics with the material of the Green Economy. Learning model that is expected to be able to develop an understanding of new concepts. Therefore, the inquiry learning model is used based on field work to improve students' understanding. The development of this learning model was carried out using the ADDIE method, which resulted in the conclusion that inquiry-based field methods effectively enhance the ability to understand students' environmentally friendly activities.

112 | The International Journal of Business Review (The Jobs Review) Vol.1 | No.2 |2018 


\section{REFERENCES}

Abdi, Ali.(2014).The Effect of Inquiry-based Learning Method on Students' Academic Achievement in Science Course Research 2(1): 37-41, 2014 http://www.hrpub.org DOI: 10.13189/ujer.2014.020104 Ali Abdi Department of Educational Sciences Payame noor University , PO BOX 19395-3697 Tehran, Iran

Abigail L. Kuhn and Lynne M. O’Hara (2015). Promoting Inquiry-Based Learning through National History Day

Social Education 78(3), pp 138-142 @2014 National Council for the Social Studies

Bern, Robert G. dan Patricia M. Erickson. (2001). Contextual Teaching and learning: Preparing Students for the New Economy. Tersedia dalam http://eric.ed.gov/?id=ED452376 diakses pada 12 Desember 2016.

Bloom et al. (1956). Taxonomy of Educational Objectives: The Classification of Educational Goals. New York: McKay.

Chan, Y. F.1*, Sidhu, G. K.1, Suthagar, N.1, Lee, L. F.1 and Yap, B.(2016) .Relationship of Inquiry-based Instruction on Active Learning in Higher Education. Pertanika J. Soc. Sci. \& Hum. 24 (S): 55 - 72 (2016).

Ralf R. Greenwald1 \& Ian J. Quitadamo, (2014). Mind of Their Own: Using Inquiry-based Teaching to Build Critical Thinking Skills and Intellectual Engagement in an Undergraduate Neuroanatomy Course. The Journal of Undergraduate Neuroscience Education (JUNE), Spring 2014, 12(2):A100-A106 JUNE is a publication of Faculty for Undergraduate Neuroscience (FUN) www.funjournal.org ARTICLE A 1Department of Psychology, Central Washington University, Ellensburg, WA 98926; 2Departments of Biological Sciences and Science Education, Central Washington University, Ellensburg, WA 98926.

Sehgal, Preety, Neha Singh. (2010) Impact on Eco Friendly Products on Consumer, CBS E Journal, Biz n bytes, Vol. 6 Dec, 2010. ISSN 0076-0458

ShahneynShilla.(2012). The Impact of Individual Differences on Green Purchasing of Malaysian Consumers, International Journal of Business and Social Science, Vol. 3 No. 162012.

Sharkness, Jesica, Linda De Angelo.(2011). Measuring Studengt Involvement : A Comparison of Classical Test Theory and The Response Theory in The Construction of Scale from student survey. Res-High Educ (2011) 52: 480-507 DOI : 10.1007/5 III 62-010-920

US

$$
\text { EPA (United States Environmnetal Protection }
$$
Agency).(2011).STORET/WQXCommomly Ask Questions (http://www.epa.gov/faq,html\#101) diakses pada 4 Juni 2016 
DISMAN, SUSANTI KURNIAWATI,, PUSPO DEWI DIRGANTARI/Social Inquiry Field Work Based Instruction Model To Improve Understanding Environmental Friendly Activities

Yvonne, Bayech Rebecca.(2016). Exploratory Study of MOOC Learner's Demographicsand Motivation : The Case of Student Involved in Group. Open Praxis Vol. 8 Issue 3 JuliSept 2016 pp 223-233 International Council for Open and Distance Education. 